\title{
Failure of T Cell Receptor-Anti-CD3 Monoclonal Antibody Interaction in T Cells from Marrow Recipients to Induce Increases in Intracellular lonized Calcium
}

\author{
Masahiko Yamagami, * Patrick W. McFadden, ${ }^{\ddagger}$ Susan M. Koethe, ${ }^{\ddagger}$ Voravit Ratanatharathorn, * and Lawrence G. Lum* \\ *Division of Hematology and Oncology, Department of Medicine, Wayne State University, Detroit, Michigan 48202; \\ ${ }^{\ddagger}$ Department of Pathology, Medical College of Wisconsin, Milwaukee, Wisconsin 53226
}

\begin{abstract}
There are multiple immune defects in $T$ cells from recipients after bone marrow transplantation (BMT). This study examines recipient $\mathbf{T}$ cells for increases in intracellular ionized calcium concentration $\left(\left[\mathrm{Ca}^{2+}\right]_{i}\right)$ after binding the $T$ cell receptorCD3 complex with anti-CD3 MAb.

PBL from 10 of 23 short-term recipients ( $<1$ yr after BMT) responded poorly ( $<35 \%$ of control) to anti-CD3 stimulation and PBL from 9 of 23 had blunted calcium flux responses (35-70\% of control). Purified $\mathrm{CD2}^{+}, \mathrm{CD56}^{-}$cells from seven additional short-term recipients including three autologous marrow recipients were closely examined, and a sizable proportion of $\mathrm{CD3}^{+}$cells from six of seven recipients did not increase $\left[\mathrm{Ca}^{2+}\right]_{i}$ after anti-CD3 stimulation. The decreased magnitude of the responses was due to decreased numbers of responding cells and not to a decrease in mean $\mathrm{CD3}$ fluorescent intensity or in calcium flux responses on a single cell basis. Five of seven long-term recipients ( $>1 \mathrm{yr}$ after BMT) had PBL that responded normally and two of seven had PBL with blunted calcium flux responses.

The data show that the signal transduction response mediated by the CD3-antigen receptor as measured by calcium flux is defective early after autologus or allogeneic BMT. ( $J$. Clin. Invest. 1990. 86:1347-1351.) Key words: bone marrow transplantation $\bullet T$ cell receptor $\bullet$ calcium flux $\bullet$ anti-CD3
\end{abstract}

\section{Introduction}

Bone marrow transplantation (BMT) ${ }^{1}$ is effective treatment for hematologic malignancies or aplastic anemia (1). There are multiple defects in the activation, differentiation, and prolifer-

Address reprint requests to Dr. Lawrence G. Lum, Wayne State University, Division of Hematology and Oncology, P. O. Box 02188, Detroit, MI 48202-0188. 1990

Received for publication 12 June 1989 and in revised form 30 May

1. Abbreviations used in this paper: Ara-C, cytosine arabinoside; BMT, bone marrow transplantation; cGVHD, chronic graft-versus-host disease; CSA, cyclosporin A; CY, cyclophosphamide; MCW, Medical College of Wisconsin; SRBC, sheep red blood cells; TCR, T cell receptor; WSU, Wayne State University.

J. Clin. Invest.

(C) The American Society for Clinical Investigation, Inc. $0021-9738 / 90 / 10 / 1347 / 05 \quad \$ 2.00$

Volume 86, October 1990, 1347-1351 ation of $\mathbf{T}$ and B cells from marrow recipients after BMT (reviewed in reference 2). The molecular mechanisms responsible for these defects have not been elucidated. Previous studies suggest that a key defect may be the inability of recipient $T$ cells to respond to triggering by antigen. An essential step in signal transmission from the cell surface to the cytosol is an increase in intracellular ionized calcium concentration $\left(\left[\mathrm{Ca}^{2+}\right]_{i}\right)$ after membrane stimulation. The changes in $\left[\mathrm{Ca}^{2+}\right]_{i}$ in single cells of a defined phenotype can be assessed by using indo- 1 and flow cytometry $(3,4)$. This study addresses the question of whether the binding of anti-CD3 antibodies to CD3 molecules and the T cell receptor complex (TCR-CD3 complex) of $\mathrm{T}$ cells from marrow recipients can induce normal increases in $\left[\mathrm{Ca}^{2+}\right]_{i}$. To perform these studies, we used the anti-CD3 MAb 38.1 to stimulate recipient $T$ cells (5). Our results show impaired calcium flux in both short- and longterm recipients; however, a greater proportion of short-term recipients had $\mathrm{T}$ cells that did not respond to anti-CD3. The results suggest that time is needed for the recovery of calcium flux responses in recipient $\mathrm{T}$ cells even in recipients who received autologous marrow grafts.

\section{Methods}

Patient population. 37 marrow recipients were included in this study. All 26 of 37 recipients at the Medical College of Wisconsin (MCW) received $\mathrm{T}$ cell-depleted allogeneic marrow grafts treated with MAb $\mathrm{T}_{10} \mathrm{~B}_{9}$ (IgM isotype) and complement to reduce $\mathrm{T}$ cells by $99 \%$ after receiving cytosine arabinoside (Ara-C), cyclophosphamide (CY), steroids, and fractionated total body irradiation $(6,7) .11$ (8 allogeneic and 3 autologous) marrow recipients received unmanipulated grafts at Wayne State University (WSU) after conditioning with varying combinations of busulfan, etoposide, Ara-C and CY $(8,9)$. The aplastic anemia patients received only CY for conditioning. Postgrafting immunosuppression included cyclosporin A (CSA) at MCW and both CSA and methylprednisolone at WSU. The diseases before BMT included 3 aplastic anemia, 11 chronic myelogeneous leukemia, 8 acute nonlymphocytic leukemia, 2 acute lymphocytic leukemia, 1 chronic lymphocytic leukemia, 1 myelodysplastic syndrome, 9 lymphomas (2 Hodgkin's Disease and 7 non-Hodgkin's lymphoma), 1 brain tumor, and 1 Ewing's sarcoma patients. Table I provides the clinical data on the recipients at the time of study. Recipients $<1 \mathrm{yr}$ after grafting are considered short-term and recipients $>1 \mathrm{yr}$ after grafting are considered long-term.

Cells and reagents. PBL were isolated from heparinized whole blood by Ficoll-Hypaque density gradient centrifugation. The experiments in Table II were done with $\mathrm{T}$ cells $\left(\mathrm{E}^{+}\right)$prepared by rosetting with 2-aminoethylisothiouronium bromide (Sigma Chemical Co., St. Louis, MO) treated sheep red blood cells (SRBC; BBL Microbiology Systems, Hunt Valley, MD). All other experiments were performed with PBL. Cells were suspended in RPMI 1640 containing $25 \mathrm{mM}$ 
Table I. Summary of Recipient Characteristics

\begin{tabular}{lcc}
\multicolumn{1}{c}{ Characteristics } & $<365$ & $>365$ \\
\hline & \multicolumn{2}{c}{ d after transplant } \\
No. of Recipients & 30 & 7 \\
Sex (M:F) & $16: 14$ & $3: 4$ \\
Age at transplant & & \\
$\quad$ Median (range) & $33(17-54)$ & $25(14-48)$ \\
Days after transplant & & \\
$\quad$ Median (range) & $115(32-257)$ & $493(375-942)$ \\
Donor & & \\
$\quad$ Autologous & 3 & 0 \\
Related, HLA-matched & 18 & 6 \\
Related, partially matched & 2 & 1 \\
HLA-matched, nonrelated & 7 & 0 \\
T cell depletion (Y:N) & $21: 9$ & $5: 2$ \\
CGVHD (Y:N) & $15: 15$ & $4: 3$ \\
Medication (Y:N) & $18: 12$ & $4: 3$ \\
& & \\
\hline
\end{tabular}

Hepes, pH 7.4 (Gibco Laboratories Grand Island, NY) and 2\% heatinactivated human AB serum (Pel-Freez, Brown Deer, WI). The calcium ionophore, ionomycin (Calbiochem-Behring Corp., La Jolla, CA) was dissolved in DMSO and used at dilutions from a $5 \mathrm{mg} / \mathrm{ml}$ stock solution. The acetoxymethyl ester of indo-1 (Molecular Probes, Inc., Eugene, OR) was dissolved in DMSO and stored in the dark at $-20^{\circ} \mathrm{C}$. Dr. Jeffrey A. Ledbetter (Oncogen, Seattle, WA) kindly provided 38.1, IgM isotype mouse anti-CD3 MAb. NKH1-RD1 (phycoerythrin-conjugated anti-CD56) and T3-FITC (FITC-conjugated anti-CD3) were purchased from Coulter Electronics (Hialeah, FL).

Intracellular ionized calcium assay. The procedure for the assessing $\left[\mathrm{Ca}^{2+}\right]_{\mathrm{i}}$ in single cells has been described (4). Briefly, cells were loaded for $45 \mathrm{~min}$ with indo-1 at a concentration of $10 \mu \mathrm{g} / \mathrm{ml}$. After loading, the cells were washed, resuspended in fresh medium at $1 \times 10^{6} / \mathrm{ml}$, and stored in the dark at room temperature until analysis. Before each assay, indo-1-loaded cells were equilibrated at $37^{\circ} \mathrm{C}$ and analyzed by flow cytometer (Coulter Electronics) at 200-400 cells/s. For each cell analyzed, the ratio of violet to blue fluorescence was digitally calculated in real time. In the $\mathrm{CD}^{+}$-enriched experiments (Table II), $\mathrm{E}^{+}$ cells were stained with anti-CD56 MAb (NKH1-RD1), washed, and $\mathrm{CD}^{+} 6^{+}$cells were electronically gated out by flow cytometer. The $\mathrm{E}^{+}$ cells were 86 to $98 \% \mathrm{CD3}^{+}$except in one case where they were $55 \% \mathrm{CD}^{+}$.

Results from indo-1 analyses were stored as "dot plots" in which the $y$-axis represents the indo- 1 violet to blue fluorescence ratio and the $x$-axis represents elapsed time. The "dot plots" are displayed as isometric plots, with the $z$-axis representing cell number. The isometric displays were also analyzed by programs that calculated the mean indo- 1 violet to blue fluorescence ratio or the percentage of responding cells vs time. The percentage of responding cells was calculated by subtracting the baseline (prestimulation) data from the poststimulation data. After subtracting the baseline data, the data of only positive cells were used to calculate the mean indo- 1 violet to blue ratio of responding cells $(V / B)$. The $V / B$ indicates calcium flux responses from only the responding cells. Statistical differences were examined by the Wilcoxon rank sum test or the pooled two-sample $t$ procedure.

\section{Results}

Calcium flux after 38.1 in normal PBL. While no change in $\left[\mathrm{Ca}^{2+}\right]_{\mathrm{i}}$ response was seen without stimulation during a 10 -min interval, there was a rapid rise in $\left[\mathrm{Ca}^{2+}\right]_{\mathrm{i}}$ after binding 38.1 to $\mathrm{T}$ cells in PBL (Fig. $1 \mathrm{~A}$ ), in which 38.1 was added to cell suspension $1 \mathrm{~min}$ after starting the assay. The percentage of responding cells $(\mathrm{RC} \%)$ and $V / B$ were computed for each 15 -s interval. The peak of $V / B$ occurred first and was followed by a gradual increase of RC\%. To analyze both variables, all data between 1 and $4 \mathrm{~min}$ after stimulation were pooled and recalculated. In normal PBL, the average RC\% was $46.9 \pm 9.2 \%$ (range $37.0-60.0 \%, n=12$ ) and the average $V / B$ was $24.7 \pm 3.3$ (range 20.1-30.6).

Calcium responses in $P B L$ of short-term recipients. Unlike normal PBL responses, most short-term recipients responded poorly to activation with 38.1 as depicted in Fig. $1 B$ or Fig. 1 $C$. The mean RC\% and $V / B$ for PBL from short-term recipients were $22.1 \pm 14.1 \%$ (range $1.9-56.5 \%, n=23$ ) and $24.7 \pm 3.2$ (range 17.6-29.7), respectively. Fig. $2, A$ and $B$ show the data for studies using PBL of 23 short- and 7 long-term recipients. There was a significant difference in RC\% between the PBL of short-term recipients and the PBL of normal controls $(P$

Table II. Calcium Flux Responses in Purified T Cells

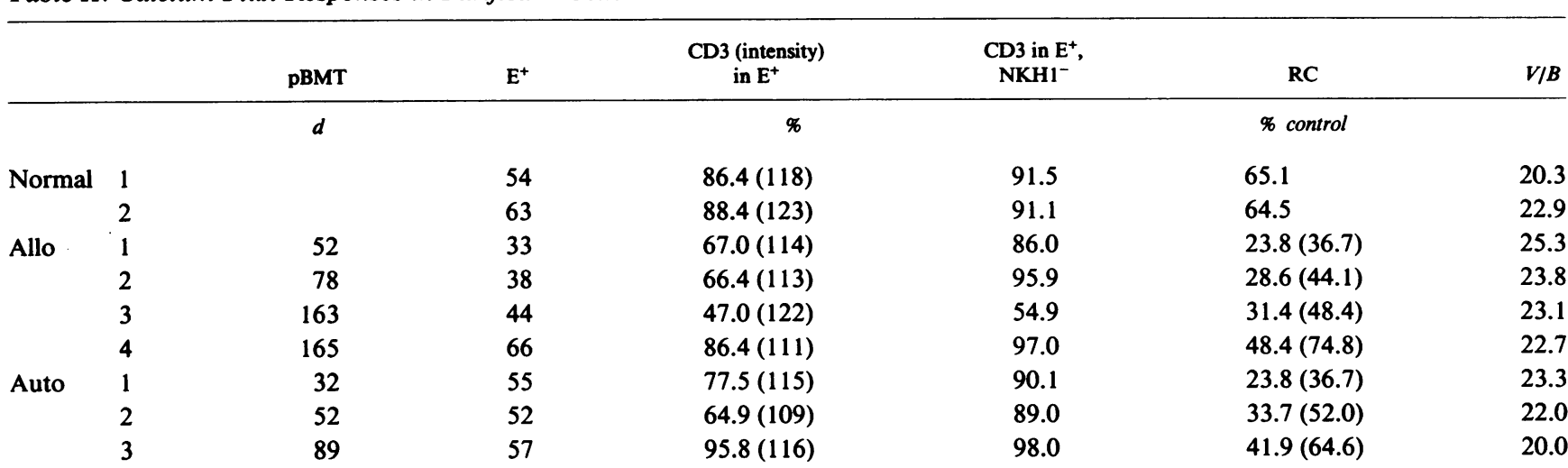

Two normal controls, four allogeneic recipients, and three autologous recipients were studied. $\mathrm{E}^{+}$cells were separated from PBL by rosetting with SRBC and stained with NKH1-RD1 after indo-1 loading. Those cells were tested for calcium flux responses by stimulation with 38.1 after the $\mathrm{CD}^{+} 6^{+}$cells were gated out. To confirm purity of the cell populations, $\mathrm{E}^{+}$cells were stained with both T3-FITC and NKH1-RD1 and analyzed in flow cytometer. \%CD3 in $\mathrm{E}^{+}, \mathrm{NKH}^{-}$cells were calculated from the two-color analysis data. Fluorescence intensity data is derived from logarithmic amplification. 

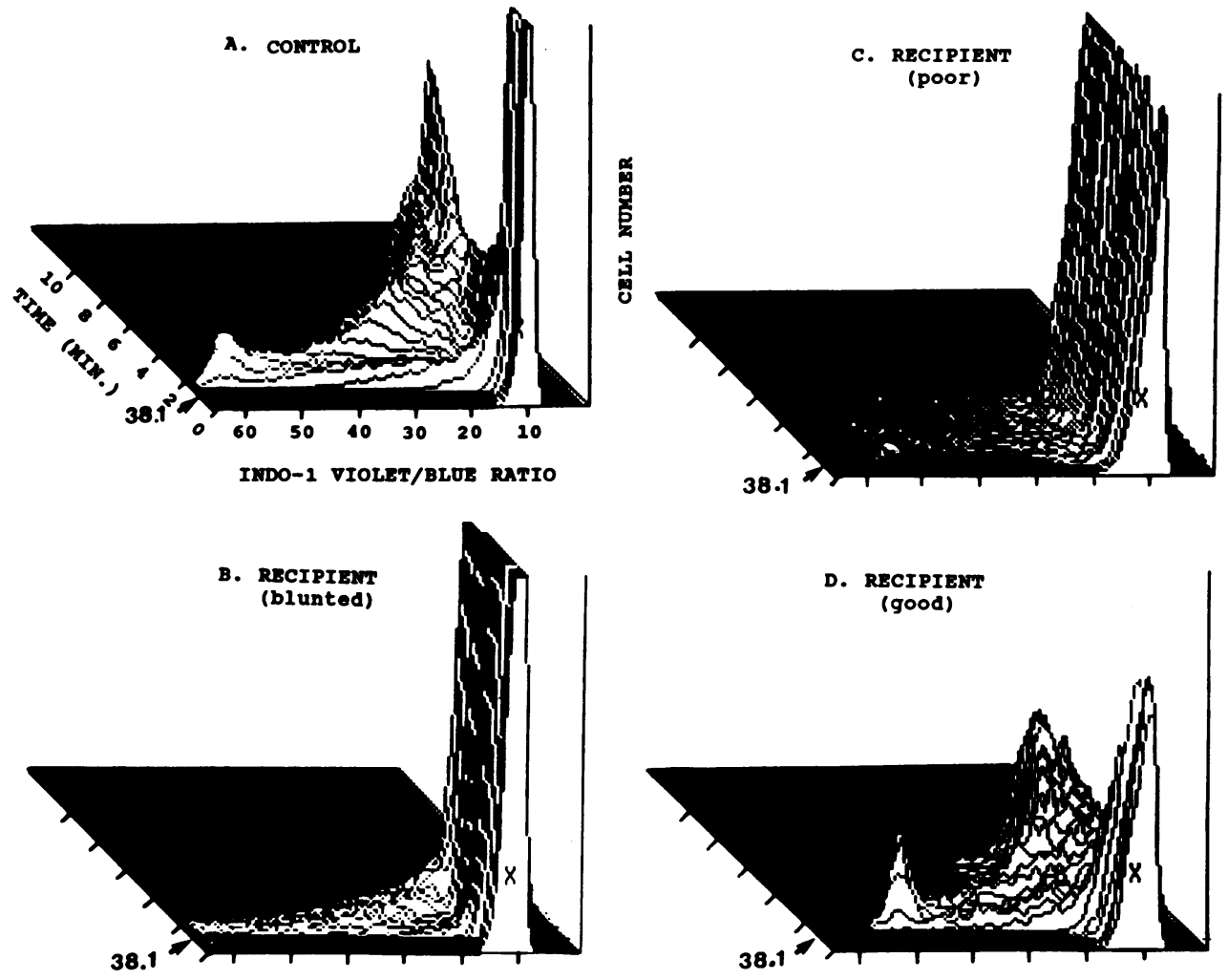

Figure 1. Real time flow cytometric analysis of indo-1-loaded PBL stimulated with MAb 38.1. Isometric plots of the mean ratio of indo-1 violet to blue fluorescence (proportional to $\left.\left[\mathrm{Ca}^{2+}\right] \mathrm{i}\right)(x$-axis) versus time ( $y$-axis) versus number of cells $(z$-axis) are shown. Cells were equilibrated at $37^{\circ} \mathrm{C}$ and analyzed at 200-400 cells/s. (A) Control PBL with $5 \mu$ lascites of 38.1 added at 1 $\min$. (B) PBL of a short-term recipient with 38.1 added at $1 \mathrm{~min}$. $(C)$ PBL of another short-term recipient with 38.1 added at $1 \mathrm{~min}$. $(D)$ PBL of a long-term recipient with 38.1 added at $1 \mathrm{~min}$.
$<0.01$ ), but not in the $V / B$ of the two groups. Since there was a range of impaired $\left[\mathrm{Ca}^{2+}\right]_{i}$ responses in the PBL from shortterm recipients, we defined percent control of $\mathrm{RC} \%$ from $35-70 \%$ as "blunted" and $<35 \%$ as "poor" like Fig. 2 B. PBL from 10 of 23 had poor $\left[\mathrm{Ca}^{2+}\right]_{\mathrm{i}}$ responses and 9 of $23 \mathrm{had}$ blunted $\left[\mathrm{Ca}^{2+}\right]_{i}$ responses. Blunted calcium responses were due to reductions in the number of responding cells. $V / B$ was nearly normal even when the $\mathrm{RC} \%$ was low. Several recipients had a small population of cells that showed high preexisting $\left[\mathrm{Ca}^{2+}\right]_{\mathrm{i}}$ before 38.1 activation. Ionomycin induced nearly normal calcium flux even in poorly responding cells from shortterm recipients.

Calcium responses in $P B L$ of long-term recipients. As depicted in Fig. $1 \mathrm{D}$, the $\left[\mathrm{Ca}^{2+}\right]_{\mathrm{i}}$ responses of PBL from 5 of 7 long-term recipients after 38.1 activation were nearly normal. PBL from two long-term recipients had blunted $\left[\mathrm{Ca}^{2+}\right]_{i}$ responses. The mean $\mathrm{RC} \%$ and $V / B$ of long-term recipients were $50.8 \pm 12.1 \%$ (range 28.9-61.1\%, $n=7$ ) and 27.5 22.1 (range 23.7-29.7), respectively. There were no statistical differences in both the $\mathrm{RC} \%$ and the $V / B$ between PBL of long-term recipients and control subjects.

Correlation with clinical factors. Fig. 2, $A$ and $B$ present the relationships between the presence or absence of chronic graft versus host disease (CGVHD), the type of transplant and RC\%. A number of recipients with CGVHD were studied while undergoing immunosuppressive therapy for their cGVHD. In some patients with CGVHD, the use of CSA and methylprednisolone did not impair calcium flux responses. There were no statistical correlations between the above mentioned variables.

Calcium responses in $T$ cells of short-term recipients. The defects seen in unfractionated PBL from marrow recipients leave the following unanswered questions. (a) Are impaired calcium flux responses related to a defective $\mathrm{T}$ cell receptor complex or a decreased number of circulating or responding $\mathrm{CD}^{+}$cells? $(b)$ Are the calcium flux defects due to allogeneic effects? To address these questions, $T$ cells $\left(E^{+}\right)$from four allogeneic and three autologgous short-term recipients were

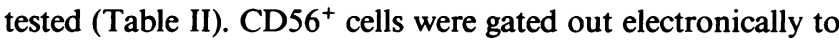
enrich $\mathrm{CD}^{+}$cells by deleting natural killer cells. Calcium flux responses of $T$ cells from both types of transplant recipients were significantly lower than normal T cells $(P<0.01)$. Average RC\% of four allogeneic, three autologous, and two normal were $33.0 \pm 10.7,33.1 \pm 9.0$, and $64.8 \pm 0.4 \%$, respectively. When the $\mathrm{RC} \%$ data are normalized, the calcium flux responses of autologous recipients were $51.0 \pm 16.6 \%$ of the control and calcium flux responses of allogeneic recipients were $51.1 \pm 14.0 \%$ of the control. As a result, purified $\mathrm{CD}^{-} \mathrm{T}$ cells highly enriched for $\mathrm{CD}^{+}$cells showed impaired calcium flux in this experiment. Finally, the mean CD3 fluorescence intensity of $\mathrm{CD3}^{+}$cells (Table II) was examined to determine if it was responsible for poor responses. CD3 intensities of the $\mathrm{CD}^{+} \mathrm{T}$ cells from the seven allogeneic and autologous recipients $(114 \pm 4, n=7)$ were not significantly different from normal CD3 ${ }^{+}$cells $(121 \pm 4, n=2)$.

\section{Discussion}

T cell activation signals are usually initiated by the binding of a ligand to either of two different cell surface molecules, the TCR-CD3 complex or the CD2 receptor (10-12). The CD2 and CD3 molecules are present on T cells (13), but CD2 molecules are also on natural killer cells (14). Therefore, CD3 activation is $T$ cell specific, whereas $C D 2$ activation is an antigen independent alternative pathway $(12,15)$, which also exists in natural killer cells. The binding of anti-CD3 MAb to the TCR-CD3 complex increases $\left[\mathrm{Ca}^{2+}\right]_{i}$, a step essential for the 
A

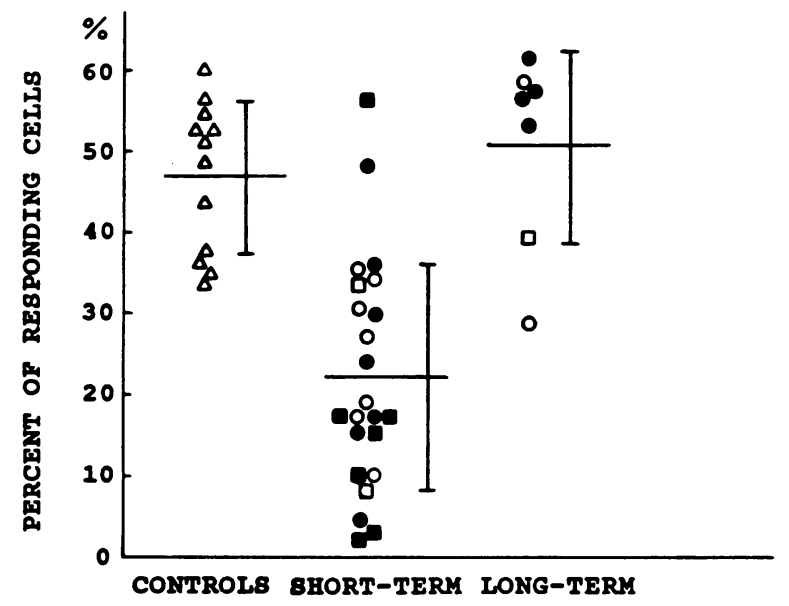

B

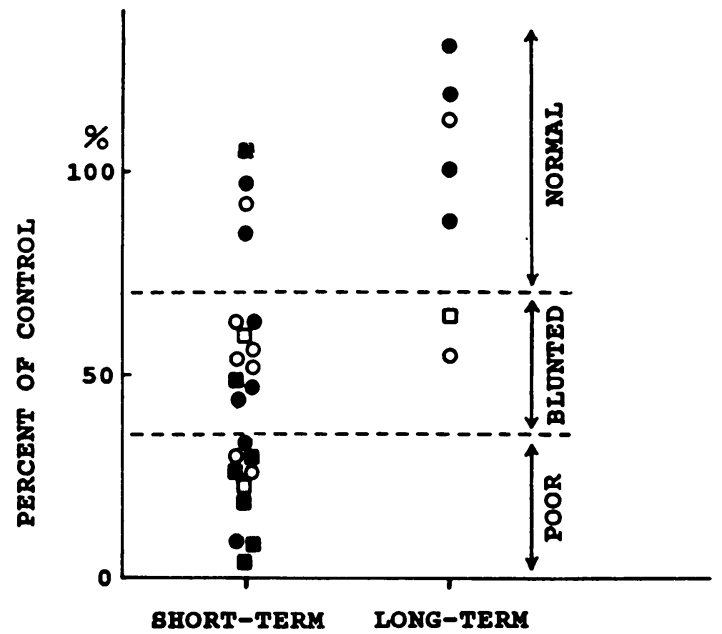

Figure 2. $(A)$ The percentage of responding cells (RC\%) in PBL of normal controls, short-term recipients and long-term recipients. The data from 1 to $4 \mathrm{~min}$ after adding $5 \mu \mathrm{l}$ ascites of 38.1 in each sample were totaled. $(B)$ The percent control of RC\% in PBL from bone marrow recipients. The data in each sample were normalized to the control of the day. O, recipients of marrow grafts from HLA-matched related doners; $\square$, recipients of marrow grafts from HLA-partially matched related donors or HLA-matched unrelated donors; solid symbol shows the presence of cGVHD. The bars show the means \pm 1 SD.

activation and proliferation of $\mathrm{T}$ cells via the TCR-CD3 complex $(10,16,17)$.

To study the CD3 pathway in marrow recipient $T$ cells, we used 38.1 to activate $T$ cells and compared their calcium flux responses with those of normal $\mathrm{T}$ cells. Since calcium flux is an early event in the activation of $\mathrm{T}$ cells, examining the calcium flux responses of recipient $T$ cells after anti-CD3 stimulation may provide insights into $\mathrm{T}$ cell maturation after BMT. This investigation shows that the expression of $\mathrm{CD} 3$ molecules on recipient $T$ cells do not functionally correlate with the responses of the T cells to anti-CD3 antibodies. To confirm this point, $T$ cells from seven additional short-term recipients were studied. The $T$ cells from these patients had lower than normal calcium flux responses, even after gating out natural killer cells by staining with phycoerythrin-conjugated anti-CD56. Although marrow recipients had slightly lower numbers of $\mathrm{CD} 3$ bearing $\mathrm{T}$ cells than normal controls (18), the decrease in the proportions of responding $\mathrm{T}$ cells within the $\mathrm{CD}^{+}$-enriched populations was greater than the decrease in the numbers of $\mathrm{CD}^{+}$cells. Therefore, the presence of $\mathrm{CD} 3$ molecules does not confer the ability to respond to anti-CD3 triggering in calcium flux assays. Blunted $\left[\mathrm{Ca}^{2+}\right]_{\mathrm{i}}$ responses were due to reductions in the number of responding cells in the $\mathrm{CD}^{+}$cell populations. The data show that if lymphocytes could respond, they would exhibit near normal or normal increases in $\left[\mathrm{Ca}^{2+}\right]_{i}$ on single-cell basis even if the percentage of responding $\mathrm{T}$ cells was low. Lymphocytes from some short-term recipients showed increases of $\left[\mathrm{Ca}^{2+}\right]_{i}$ without anti-CD3 activation. This latter observation suggests in vivo activation by clinical events such as GVHD or related phenomena. However, there were no correlations between clinical states such as acute or chronic GVHD and high basal $\left[\mathrm{Ca}^{2+}\right]_{i}$.

Studies of HIV-1-infected CD4 ${ }^{+}$cells showed that $\mathrm{CD}^{+}$ cells failed to respond to anti-CD3 MAb binding to the TCR by increasing their $\left[\mathrm{Ca}^{2+}\right]_{i}(5)$. The findings in the short-term recipients may be analogous to the HIV-1-infected $\mathrm{CD}^{+}$cells; that is, $\mathrm{CD}^{+}$cells are present, but are not capable of responding to anti-CD3 stimulation. CD5 is the other important antigen for $\mathrm{T}$ cell activation, especially for calcium flux response (19). In an earlier study, PBL containing predominantly $\mathrm{CD}^{+}, \mathrm{CD}^{-}$cells from representative $\mathrm{BMT}$ recipient failed to respond after OKT3 stimulation; $\mathrm{CD}^{+}, \mathrm{CD}^{-}$cells from the patient produced IL 2 and mediated lectin-induced cytotoxicity (20). It is also reported that $T$ cells from some marrow recipients had TCR $\gamma, \delta$ instead of TCR $\alpha, \beta(21)$. The inability of $\mathrm{T}$ cells from marrow graft recipients to upregulate their $\left[\mathrm{Ca}^{2+}\right]_{\mathrm{i}}$ after TCR interaction with antigen may be a central defect in the first 6 mo after BMT. This defect precedes a series of critical T cell functions such as expression of IL 2 receptors as well as IL 2 synthesis. These results help explain earlier reports that show defective helper $\mathrm{T}$ cell function by purified $\mathrm{CD}^{+}$cells, impaired T cell-proliferative responses to antigens and mitogens, and defective IL 2 synthesis (reviewed in reference 2). Future studies on the activation of the membrane enzyme phospholipase $\mathrm{C}$, coupling of $\mathrm{G}$ protein phospholipase $\mathrm{C}$, inositol triphosphate and diacylglycerol, and protein kinase C (22), are needed to localize the step at which the $T$ cell defects occur in marrow graft recipients.

Since many clinical factors affect the process of immune reconstitution, it is difficult to correlate calcium flux responses with clinical states. In in vitro studies, cGVHD is associated with delays in the recovery of helper $\mathrm{T}$ cell functions, proliferative responses, and lymphokine synthesis (2). Although the numbers are small, PBL from long-term recipients with cGVHD who also received medication did not have defects in calcium flux responses. These observations suggest that the immune phenomena associated with CGVHD are not directly linked to defects in TCR-CD3 activation with anti-CD3 antibodies. Although the statistical analyses could not be done, minor and major histocompatibility differences seemed to augment impaired calcium responses.

We describe a defect that is present early in the activational process of recipient $T$ cells. Such defects may account for why $T$ cells from short-term recipients can not be activated to proliferate or synthesize critical lymphokines after stimulation. One explanation for this abnormality is that the TCR on recipient $T$ cells may be "immature" or partially abnormal in its 
expression rendering the $\mathrm{T}$ cells unresponsive to anti-CD3 stimulation. Future studies are needed to determine whether there are structural abnormalities in the TCR of recipient $T$ cells or if there are activation pathways that are defective in the membrane signaling process.

\section{Acknowledgments}

We thank Michael J. Anhalt, Bernadette R. Giddings, and Paula J. Zamiatowski for their assistance.

This work was supported in part by American Cancer Society (ACS). Grant IM-536; V. Ratanatharathorn was supported in part by an ACS Grant for Institutional Application for Clinical Oncology Fellowship. M. Yamagami was supported in part by the Department of Pediatrics, Kanazawa University Hospital and the Division of Hematology and Oncology, Wayne State University.

\section{References}

1. Thomas, E. D., R. Storb, R. A. Clift, A. Fefer, F. L. Johnson, E Neiman, K. G. Lerner, H. Glucksberg, and C. D. Buckner. 1975. Bone-marrow Transplantation. N. Engl. J. Med. 292:832-843, 895-902.

2. Lum, L. G. 1987. A review: The kinetics of immunologic recovery after human marrow transplantation. Blood. 69:369-380.

3. Gelfand, E. W., R. K. Cheung, and S. Grinstein. 1986. Mitogeninduced changes in $\mathrm{Ca}^{2+}$ permeability are not mediated by voltagegated $\mathrm{K}^{+}$channels. J. Biol. Chem. 261:11520-11523.

4. Rabinovitch, P. S., C. H. June, A. Grossmann, and J. A. Ledbetter. 1986 . Heterogeneity among $\mathrm{T}$ cells in intracellular free calcium responses after mitogen stimulation with PHA or anti-CD3. Simultaneous use of indo- 1 and immunofluorescence with flow cyometry. $J$. Immunol. 137:952-961.

5. Linette, G. P., R. J. Hartzman, J. A. Ledbetter, and C. H. June. 1988. HIV-1-infected $T$ cells show a selective signaling defect after perturbation of CD3/antigen receptor. Science. (Wash. DC). 241:573576.

6. Truitt, R. L. and R. C. Ash. 1987. Manipulation of T-cell content in transplanted human bone marrow: effect on GVH and GVL reactions. In Cellular Immunotherapy of Cancer. Alan R. Liss, Inc., New York. 409-421.

7. Ash, R. C., J. Casper, M. S. Serwint, C. Coffey, J. E. Bruckman, R. Truitt, M. Greenwood, J. Geil, E. Romond, B. Camitta, J. McDonald, J. Thompson, and Y. Maruyama. 1987. Extending the application of allogeneic marrow transplantation for leukemic patients who lack matched sibling donors in concert with T-cell depletion for GVHD prophylaxis. In Progress in Bone Marrow Transplantation. R. P. Gale and R. Champlin, editors. Alan R. Liss, Inc., New York. 365-379.

8. Ratanatharathorn, V., C. Karanes, S. Cronin, M. Dan, M. de Planque, M. Frey, C. Leisz, L. Lum, K. Schultz, P. Steele, J. Uberti, and $L$. Sensenbrenner. Preparative regimen using busulfan (BU), cytosine arabinoside (ARA-C) and cyclophosphamide (CY) in allogeneic bone marrow transplantation. (International Society for Experimental Hematology Abstract, 1990.)
9. Sensenbrenner, L., C. Karanes, C. Leisz, J. Uberti, and V. Ratanatharathorn. Autologous (AUTOBMT) or allogeneic (ALLOBMT) bone marrow transplantation (BMT) in patients with lymphomas. (ISEH Abstract, 1990.)

10. Weiss, A., J. Imboden, D. Shoback, and J. Stobo. 1984. Role of T3 surface molecules in human T-cell activation: T3-dependent activation results in an increase in cytoplasmic free calcium. Proc. Natl. Acad. Sci. USA. 81:4169-4173.

11. Meuer, S. C., R. E. Hussey, D. A. Cantrell, J. C. Hodgdon, S. F. Schlossman, K. A. Smith, and E. L. Reinherz. 1984. Triggering of the $\mathrm{T} 3-\mathrm{Ti}$ anti-receptor complex results in clonal $\mathrm{T}$ cell proliferation through an interleukin 2 dependent autocrine pathway. Proc. Natl. Acad. Sci. USA. 81:1509-1513.

12. Meuer, S. C., R. E. Hussey, M. Fabbi, D. A. Fox, O. Acuto, K. A. Fitzgerald, J. C. Hodgdon, J. P. Protentis, S. F. Schlossman, and E. L. Reinherz. 1984. An alternative pathway of T-cell activation: a functional role for the $50 \mathrm{Kd}$ Tll sheep erythrocyte receptor protein. Cell. 36:897-906.

13. Meuer, S. C., O. Acuto, R. E. Hussey, J. C. Hodgdon, K. A. Fitzgerald, S. F. Schlossman, and E. L. Reinherz. 1983. Evidence for the $\mathrm{T} 3$ associated $90 \mathrm{Kd}$ heterodimer as the $\mathrm{T}$ cell antigen receptor. Nature (Lond.). 33:808-810.

14. Perussia, B., G. Trinchieri, A. Jackson, N. L. Warner, J. Faust, H. Rumpold, D. Kraft, and L. L. Lanier. 1984. The Fc receptor for IgG in human natural killer cells: phenotypic, functional, and comparative studies with monoclonal antibodies. J. Immunol. 133:180-189.

15. Fox, D. A., R. E. Hussey, K. A. Fitzgerald, A. Bensussan, J. F. Daley, S. F. Schlossman, and E. L. Reinherz. 1985. Activation of human thymocytes via the $50 \mathrm{Kd}$ Tll sheep erythrocyte binding protein induces the expression of interleukin 2 receptors in both $\mathrm{T}^{+}$and $\mathrm{T3}^{-}$ populations. J. Immunol. 134:330-335.

16. Gelfand, E. W., G. B. Mills, R. K. Cheung, J. W. W. Lee, and S. Grinstein. 1987. Transmembrane ion fluxes during activation of human $\mathrm{T}$ lymphocytes: role of $\mathrm{Ca}^{2+}, \mathrm{Na}^{+} / \mathrm{H}^{+}$exchange and phospholipid turnover. Immunol. Rev. 95:59-87.

17. Imboden, J. B., A. Weiss, and J. D. Stobo. 1985. The antigen receptor on a human $\mathrm{T}$ cell line initiates activation by increasing cytoplasmic free calcium. J. Immunol. 134:663-665.

18. de Bruin, H. G., A. Astaldi, T. Leupers, R. J. van de Griend, L. J. Dooren, P. T. A. Schellekens, H. J. Tanke, M. Roos, and J. M. Vossen. 1981. T lymphocyte characteristics in bone marrow-transplanted patients. II. Analysis with monoclonal antibodies. J. Immunol. 127:244-251.

19. June, C. H., P. S. Rabinovitch, and J. A. Ledbetter. 1987. CD5 antibodies increase intracellular ionized calcium concentration in $\mathrm{T}$ cells. J. Immunol. 138:2782-2792.

20. Bierer, B. E., S. J. Burakoff, and B. R. Smith. 1989. A large proportion of $\mathrm{T}$ lymphocytes lack CD5 expression after bone marrow transplantation. Blood. 73:1359-1366.

21. Vilmer, E., F. Triebel, V. David, C. Rabian, M. Schumpp, G. Leca, L. Degos, T. Hercend, F. Sigaux, and A. Bensussan. 1988. Prominent expansion of circulating lymphocytes bearing T-cell receptors, with preferential expression of variable genes after allogeneic bone marrow transplantation. Blood. 72:841-849.

22. Chatila, T., R. Wong, M. Young, R. Miller, C. Terhorst, and R. S. Geha. 1989. An immunodeficiency characterized by defective signal transduction in T lymphocytes. N. Engl. J. Med. 320:696-702 